\title{
Seroprevalence of Toxoplasma gondii in commensal rodents sampled across Senegal, West Africa
}

\author{
Carine Brouat ${ }^{1, *}$, Christophe Amidi Diagne ${ }^{1,2}$, Khadija Ismail ${ }^{3}$, Abdelkrim Aroussi ${ }^{3}$, Ambroise Dalecky ${ }^{4}, \mathrm{Khalilou} \mathrm{Bâ}^{2}$, \\ Mamadou Kane ${ }^{2}$, Youssoupha Niang ${ }^{2}$, Mamoudou Diallo ${ }^{2}$, Aliou Sow ${ }^{2}$, Lokman Galal ${ }^{3}$, Sylvain Piry ${ }^{1}$, Marie-Laure Dardé ${ }^{3}$, \\ and Aurélien Mercier ${ }^{3}$ \\ ${ }^{1}$ CBGP, IRD, CIRAD, INRA, Montpellier SupAgro, Univ. Montpellier, 755 avenue du campus Agropolis, 34988 Montferrier-sur-Lez \\ cedex, France \\ 2 BIOPASS, CBGP-IRD, ISRA, UCAD, Campus de Bel-Air, BP 1386, Dakar CP 18524, Senegal \\ 3 UMR-S 1094, Neuroépidémiologie Tropicale, INSERM, Univ. Limoges, 2 rue du Dr Marcland, 87025 Limoges, France \\ ${ }^{4}$ LPED, IRD, Aix Marseille Univ., Centre St Charles, case 10, 3 place Victor Hugo, CS 80249, 13331 Marseille cedex 03, France
}

Received 6 February 2018, Accepted 20 June 2018, Published online 16 July 2018

\begin{abstract}
Risks related to Toxoplasma gondii infection in humans remain poorly known in Senegal. Although rodent surveys could help to assess the circulation of $T$. gondii, they have seldom been set up in sub-Saharan Africa. The aim of this study was to examine Toxoplasma seroprevalence in rodents from villages and towns across Senegal. Rodents were sampled in 40 localities using a standardised trapping protocol. Detection of $T$. gondii antibodies was performed on 1205 rodents, using a modified agglutination test (MAT) technique. Seroprevalence data were analysed depending on geography, the local rodent community, and individual characteristics of the rodent hosts. We found 44 seropositive rodents from four different species (Mastomys erythroleucus, Mastomys natalensis, Mus musculus domesticus, Rattus rattus). Toxoplasma seroprevalence was low, averaging $4 \%$ in the localities. Higher Toxoplasma seroprevalence (up to $24 \%$ ) was found in northern Senegal, a region known to be the heart of pastoral herding in the country.
\end{abstract}

Key words: Africa, rodents, Senegal, seroprevalence, Toxoplasma gondii.

Résumé - Séroprévalence de Toxoplasma gondii chez les rongeurs commensaux au Sénégal, Afrique de l'Ouest. Les risques liés à l'infection par Toxoplasma gondii chez l'homme restent mal connus au Sénégal. Bien que les rongeurs soient considérés comme des marqueurs pertinents de la circulation de $T$. gondii, peu d'études ont ciblé ces hôtes en Afrique sub-saharienne. Le but de cette étude était d'étudier la séroprévalence de Toxoplasma chez les rongeurs des villes et des villages du Sénégal. Les rongeurs ont été échantillonnés dans 40 localités avec un protocole de piégeage standardisé. La détection des anticorps contre T. gondii a été faite sur 1205 rongeurs avec un test d'agglutination modifié. Les données de séroprévalence ont été analysées en fonction de la géographie, de la communauté locale de rongeurs et de caractéristiques individuelles du rongeur. Nous avons trouvé 44 individus séropositifs, de quatre espèces différentes (Mastomys erythroleucus, Mastomys natalensis, Mus musculus domesticus, Rattus rattus). La séroprévalence moyenne est faible, de l'ordre de $4 \%$ au sein des localités. Les plus fortes séroprévalences (jusqu'à $24 \%$ ) ont été observées dans le Nord du Sénégal, une région connue pour être le cœur de l'élevage pastoral dans le pays.

\section{Introduction}

Toxoplasma gondii [25] is an intracellular pathogen with a worldwide distribution [17]. In humans, infections range in severity from asymptomatic to lethal, and are particularly dangerous to the unborn child during pregnancy and to

\footnotetext{
*Corresponding author: carine.brouat@ird.fr
}

immunosuppressed patients. Transmission to humans may occur either congenitally, or by ingestion of undercooked meat containing tissue cysts, or of food and water contaminated with oocysts shed into the environment in the faeces of felids. Although felids are the only known definitive host of $T$. gondii, all homoeothermic animals may act as intermediate hosts [33]. Rodents constitute important prey for domestic felids, and are among the few wild mammals to persist in villages and towns. 


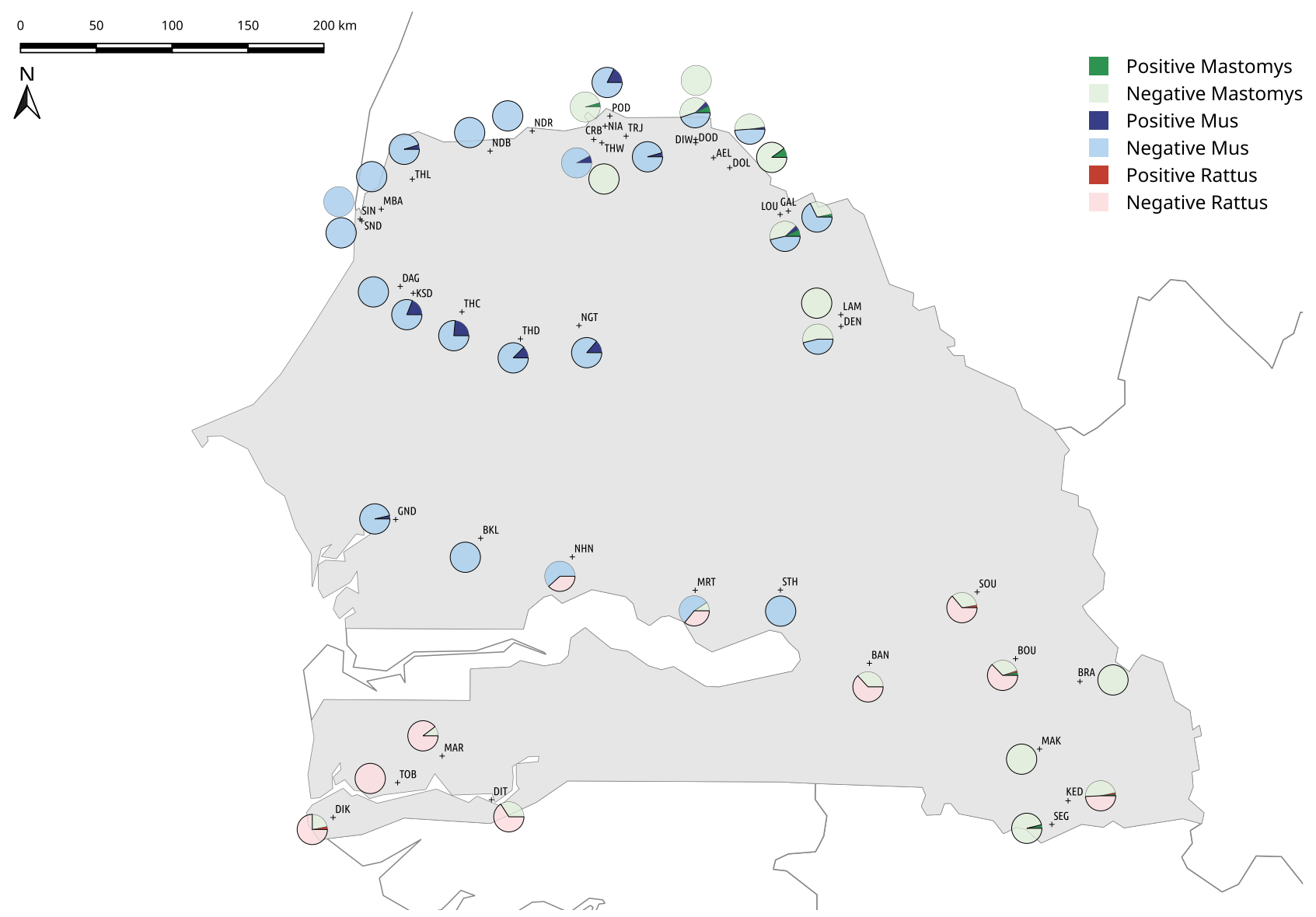

Fig. 1. Seroprevalence of Toxoplasma gondii in rodent communities in villages and towns in Senegal. See Table 1 for locality codes. Light and dark colours indicated the percentage of negative $(-)$ and positive $(+)$ rodents of each dominant species in the community (Mus musculus, Rattus rattus or Mastomys spp.), respectively.

For this reason, they are often considered relevant markers to assess the circulation of $T$. gondii in commensal habitats $[23,30]$.

In sub-Saharan Africa, human seroprevalence is highly variable, with reported values ranging from $4 \%$ to $83 \%$ [20]. In Senegal, T. gondii infection in humans has been found to vary between $4 \%$ and $40 \%[19,24]$. However, most studies concerned the city of Dakar and the distribution of risks related to the disease across the country remains largely unknown. Moreover, the seroprevalence of Toxoplasma in animal populations has rarely been characterised in Senegal $[8,12]$.

In this study, we provide serological data for $T$. gondii obtained from 1205 rodents sampled in villages and towns in Senegal. Seroprevalence data were analysed regarding the geographical location of the sampling locality, its rodent community, and the individual characteristics of the rodent hosts.

\section{Material and methods}

\section{Sampling}

Fieldwork was conducted in 40 localities in Senegal between 2011 and 2014 (Fig. 1, Table 1). Trapping within private properties was performed with prior agreement from local authorities. All animal-related procedures were carried out under our laboratory authorisation for experiments on wild animals (No. D 34-169-1), and followed the official guidelines of the American Society of Mammalogists [31]. The detailed description of the standardised trapping protocol used here was provided in [7]. Rodents were captured alive and euthanised using cervical dislocation, weighed to the nearest $0.5 \mathrm{~g}$, sexed and dissected. Intra-cardiac blood was sampled immediately after death and spotted onto Whatman No. 3 papers that were air-dried and then stored in a plastic bag at room temperature (RT) in the field and then at $4{ }^{\circ} \mathrm{C}$ in the laboratory.

Rodents were identified to the species level using morphologic tools [14]. The rodent community was characterised at each locality using trap success (e.g., the ratio between the number of captured rodents and active traps set), as a proxy for relative rodent abundance, and Simpson's diversity index [32].

Dried blood samples were used for the detection of T. gondii antibodies using a modified agglutination test (MAT) technique [9] adapted for dried blood samples, with a cut-off titre at 1:16 [20]. Two $5 \mathrm{~mm}$ diameter dried blood spots were punched out of each blotting paper circle and placed into the well of a flat bottomed microtitre plate. The blood was eluted out in $80 \mu \mathrm{L}$ of phosphate buffered saline, $\mathrm{pH} 7.2$ (bioMérieux). Plates were covered and left to elute overnight 
Table 1. Rodent sampling in Senegal, number of seropositive individuals for Toxoplasma gondii, and mean seroprevalence per locality and rodent species.

\begin{tabular}{|c|c|c|c|c|c|c|c|c|c|c|c|c|c|c|}
\hline \multirow[t]{2}{*}{ Locality } & \multirow[t]{2}{*}{ Code } & \multirow[t]{2}{*}{ Long. } & \multirow[t]{2}{*}{ Lat. } & \multirow[t]{2}{*}{$N^{\mathrm{a}}$} & \multirow[t]{2}{*}{$N_{\text {sero }} \mathrm{b}$} & \multirow{2}{*}{$\begin{array}{l}\mathrm{SP}^{\mathrm{c}} \\
(\%)\end{array}$} & \multirow[t]{2}{*}{$\mathrm{S}^{\mathrm{d}}$} & \multirow[t]{2}{*}{$\mathrm{T}_{\mathrm{S}}^{\mathrm{e}}$} & \multicolumn{6}{|c|}{ Rodent species $^{f}$} \\
\hline & & & & & & & & & $\begin{array}{c}\text { A. } \\
\text { niloticus }\end{array}$ & $\begin{array}{c}\text { M. } \\
\text { erythroleucus }\end{array}$ & $\begin{array}{c}M . \\
\text { s natalensis } \\
\end{array}$ & $\begin{array}{c}P . \\
\text { daltoni }\end{array}$ & $\begin{array}{c}\text { M. m. } \\
\text { domesticus }\end{array}$ & R. rattus \\
\hline Aere Lao & AEL & -14.32 & 16.40 & 73 & 41 & 2.4 & 0.58 & 0.36 & & $22 \backslash 20 \backslash 0$ & & & $51 \backslash 21 \backslash 1$ & \\
\hline Badi Nieriko & BAN & -13.38 & 13.38 & 89 & 38 & 0 & 0.72 & 0.41 & & $14 \backslash 14 \backslash 0$ & & $01 \backslash 00 \backslash-$ & & $74 \backslash 24 \backslash 0$ \\
\hline Boutougoufara & BOU & -12.49 & 13.40 & 67 & 65 & 4.6 & 0.46 & 0.28 & $01 \backslash 01 \backslash 0$ & $21 \backslash 21 \backslash 2$ & & $05 \backslash 05 \backslash 0$ & & $40 \backslash 38 \backslash 1$ \\
\hline Bransan & BRA & -12.10 & 13.26 & 41 & 32 & 0 & 0.67 & 0.33 & $01 \backslash 01 \backslash 0$ & $06 \backslash 04 \backslash 0$ & $33 \backslash 26 \backslash 0$ & $01 \backslash 01 \backslash 0$ & & \\
\hline Croisement Boube & CRB & -15.06 & 16.51 & 49 & 13 & 7.7 & 0.85 & 0.11 & $01 \backslash 00 \backslash-$ & $03 \backslash 00 \backslash-$ & & & $45 \backslash 13 \backslash 1$ & \\
\hline Dagathie & DAG & -16.25 & 15.63 & 30 & 20 & 0 & 1.00 & 0.29 & & & & & $30 \backslash 20 \backslash 0$ & \\
\hline Dendoudi & DEN & -13.54 & 15.39 & 49 & 39 & 0 & 0.47 & 0.20 & $03 \backslash 00 \backslash-$ & $28 \backslash 21 \backslash 0$ & & & $18 \backslash 18 \backslash 0$ & \\
\hline Diakene-Wolof & DIK & -16.64 & 12.46 & 39 & 33 & 3.0 & 0.63 & 0.36 & & $08 \backslash 07 \backslash 0$ & & $01 \backslash 01 \backslash 0$ & & $30 \backslash 25 \backslash 1$ \\
\hline Diattacounda & DIT & -15.68 & 12.57 & 52 & 45 & 0 & 0.55 & 0.42 & & $16 \backslash 15 \backslash 0$ & & $01 \backslash 01 \backslash 0$ & & $35 \backslash 29 \backslash 0$ \\
\hline Diomandou Walo & DIW & -14.43 & 16.51 & 15 & 14 & 0 & 0.88 & 0.08 & $01 \backslash 00 \backslash-$ & $14 \backslash 14 \backslash 0$ & & & & \\
\hline Dodel & DOD & -14.43 & 16.49 & 57 & 40 & 12.5 & 0.51 & 0.40 & & $33 \backslash 20 \backslash 3$ & & & $24 \backslash 20 \backslash 2$ & \\
\hline Doumnga Lao & DOL & -14.22 & 16.34 & 46 & 20 & 10.0 & 0.96 & 0.49 & $01 \backslash 00 \backslash-$ & $45 \backslash 20 \backslash 2$ & & & & \\
\hline Galoya & GAL & -13.86 & 16.08 & 94 & 31 & 3.2 & 0.66 & 0.32 & $05 \backslash 00 \backslash-$ & $14 \backslash 10 \backslash 1$ & & & $75 \backslash 21 \backslash 0$ & \\
\hline Gandiaye & GND & -16.27 & 14.24 & 29 & 28 & 3.6 & 0.93 & 0.26 & & & & & $28 \backslash 28 \backslash 1$ & \\
\hline Kedougou & KED & -12.18 & 12.55 & 65 & 59 & 3.4 & 0.50 & 0.52 & & & $30 \backslash 29 \backslash 1$ & & & $35 \backslash 30 \backslash 1$ \\
\hline Keur Seyni Dieng & KSD & -16.17 & 15.59 & 23 & 23 & 17.4 & 0.84 & 0.22 & $02 \backslash 02 \backslash 0$ & & & & $21 \backslash 21 \backslash 4$ & \\
\hline Lambago & LAM & -13.54 & 15.46 & 24 & 20 & 0 & 0.92 & 0.07 & $01 \backslash 00 \backslash-$ & $23 \backslash 20 \backslash 0$ & & & & \\
\hline Lougue & LOU & -13.91 & 16.06 & 56 & 41 & 12.2 & 0.47 & 0.41 & $02 \backslash 00 \backslash-$ & $26 \backslash 20 \backslash 3$ & & & $28 \backslash 21 \backslash 2$ & \\
\hline Mako & MAK & -12.35 & 12.86 & 52 & 26 & 0 & 0.86 & 0.46 & & & $48 \backslash 26 \backslash 0$ & $04 \backslash 00 \backslash-$ & & \\
\hline Marsassoum & MAR & -15.98 & 12.83 & 34 & 30 & 0 & 0.74 & 0.41 & & $03 \backslash 03 \backslash 0$ & & $02 \backslash 01 \backslash 0$ & & $29 \backslash 26 \backslash 0$ \\
\hline Mbakhana & MBA & -16.37 & 16.09 & 30 & 23 & 0 & 1.00 & 0.28 & & & & & $30 \backslash 23 \backslash 0$ & \\
\hline Mbirkilane & BKL & -15.75 & 14.13 & 32 & 32 & 0 & 1.00 & 0.42 & & & & & $32 \backslash 32 \backslash 0$ & \\
\hline Mereto & MRT & -14.44 & 13.82 & 68 & 62 & 0 & 0.33 & 0.37 & $09 \backslash 09 \backslash 0$ & $06 \backslash 05 \backslash 0$ & & & $30 \backslash 29 \backslash 0$ & $23 \backslash 19 \backslash 0$ \\
\hline Ndiareme & NDR & -15.44 & 16.56 & 26 & 24 & 0 & 0.86 & 0.33 & & $02 \backslash 00 \backslash-$ & & & $24 \backslash 24 \backslash 0$ & \\
\hline Ndombo & NDB & -15.70 & 16.44 & 24 & 20 & 0 & 0.92 & 0.16 & $01 \backslash 00 \backslash-$ & & & & $23 \backslash 20 \backslash 0$ & \\
\hline Nguith & NGT & -15.15 & 15.40 & 22 & 22 & 13.6 & 1.00 & 0.30 & & & & & $22 \backslash 22 \backslash 3$ & \\
\hline Niahene & NHN & -15.19 & 14.02 & 36 & 35 & 0 & 0.50 & 0.27 & $01 \backslash 01 \backslash 0$ & & & & $22 \backslash 21 \backslash 0$ & $13 \backslash 13 \backslash 0$ \\
\hline Niandane & NIA & -14.99 & 16.59 & 45 & 44 & 4.5 & 1.00 & 0.49 & & $45 \backslash 44 \backslash 2$ & & & & \\
\hline Podor & POD & -14.96 & 16.65 & 18 & 17 & 17.6 & 0.90 & 0.21 & & & & & $17 \backslash 17 \backslash 3$ & \\
\hline Segou & SEG & -12.28 & 12.41 & 31 & 31 & 3.2 & 0.73 & 0.27 & & & $26 \backslash 26 \backslash 1$ & $05 \backslash 05 \backslash 0$ & & \\
\hline Sinthiou Maleme & STH & -13.92 & 13.82 & 30 & 19 & 0 & 1.00 & 0.29 & & & & & $30 \backslash 19 \backslash 0$ & \\
\hline Soutouta & SOU & -12.72 & 13.80 & 49 & 46 & 2.2 & 0.38 & 0.26 & $10 \backslash 09 \backslash 0$ & $12 \backslash 12 \backslash 0$ & & $01 \backslash 01 \backslash 0$ & & $26 \backslash 24 \backslash 1$ \\
\hline $\begin{array}{l}\text { Saint-Louis Ile } \\
\text { Nord }\end{array}$ & SIN & -16.50 & 16.03 & 29 & 25 & 0 & 0.87 & 0.22 & & & & & $27 \backslash 25 \backslash 0$ & \\
\hline Saint-Louis Sor & SND & -16.49 & 16.02 & 26 & 24 & 0 & 1.00 & 0.41 & & & & & $26 \backslash 24 \backslash 0$ & \\
\hline Taredji & TRJ & -14.86 & 16.53 & 26 & 23 & 4.3 & 1.00 & 0.37 & & & & & $26 \backslash 23 \backslash 1$ & \\
\hline Thiamene Cayor & THC & -15.87 & 15.48 & 17 & 17 & 23.5 & 1.00 & 0.16 & & & & & $17 \backslash 17 \backslash 4$ & \\
\hline Thiamene Djolof & THD & -15.51 & 15.32 & 17 & 16 & 12.5 & 1.00 & 0.15 & & & & & $17 \backslash 16 \backslash 2$ & \\
\hline Thiewle & THW & -15.01 & 16.49 & 34 & 22 & 0 & 1.00 & 0.34 & & $34 \backslash 22 \backslash 0$ & & & & \\
\hline Thilène & THL & -16.18 & 16.27 & 26 & 21 & 4.8 & 1.00 & 0.31 & & & & & $26 \backslash 21 \backslash 1$ & \\
\hline Tobor & TOB & -16.25 & 12.67 & 34 & 24 & 0 & 0.74 & 0.43 & & $01 \backslash 00 \backslash-$ & & $04 \backslash 03 \backslash 0$ & & $29 \backslash 21 \backslash 0$ \\
\hline Total & & & & 16041 & 1205 & & & & $39 \backslash 23 \backslash 0$ & $376 \backslash 292 \backslash 13$ & $137 \backslash 107 \backslash 2$ & $25 \backslash 18 \backslash 0$ & $689 \backslash 516 \backslash 25$ & $334 \backslash 249 \backslash 4$ \\
\hline Mean seroprevalenc & ce $(\%)$ & & & & & 4.2 & & & 0.0 & 4.5 & 1.9 & 0 & 4.8 & 1.6 \\
\hline $\begin{array}{l}\text { Number of samp } \\
\text { Number of roden } \\
\text { Seroprevalence o } \\
\text { Simpson's divers } \\
\text { Trap success, cal } \\
\text { traps (e.g., those fo } \\
\text { Number of indivi }\end{array}$ & $\begin{array}{l}\text { oled rod } \\
\text { nts con } \\
\text { of } T \text {. go } \\
\text { sity ind } \\
\text { lculated }\end{array}$ & $\begin{array}{l}\text { dents; } \\
\text { sidered } \mathrm{f} \\
\text { ondii; } \\
\text { lex; } \\
\text { as the } \mathrm{r}\end{array}$ & $r$ serol & logica & al anal & lyses; & 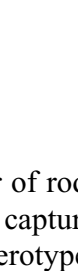 & titis & mpled & nd the numb & $r$ of traps & et in th & ouses, min & n-active \\
\hline
\end{tabular}


at RT and at $400 \mathrm{rpm}$ agitation. Ten microlitres of each eluted sample were used. Samples were screened at four serial dilutions (1:16, 1:32, 1:320 and 1:640). For serological control, fresh blood from T. gondii antibody-seronegative Swiss mice (not infected by $T$. gondii) and $T$. gondii antibody-seropositive Swiss mice (experimentally infected with control of the presence of cysts in the brain) (Mus musculus, Janvier Labs, Saint-Berthevin, France) was spotted onto a $5 \mathrm{~mm}$ diameter circle on Whatman No. 3 paper and allowed to dry at RT for $24 \mathrm{~h}$, before storage at RT in sealed bags. Antibody titres were determined by the last dilution where the agglutination pattern could be read in comparison with the negative and positive controls. Toxoplasma seroprevalence was finally calculated as the percentage of seropositive rodents in each sampling locality.

\section{Statistical analyses}

We carried out a generalised linear model (GLM) assuming a binomial distribution to test whether individual rodent seropositivity was related to geography (described by latitude and longitude coordinates of the sampled individual), rodent community diversity (Simpson index) and relative abundance (estimated using trap success) at the locality of sampling, as well as rodent species, sex and body mass (this variable was centred-reduced to avoid the confounding effect of specific differences). The interactions between rodent species and geographical coordinates were also considered in the model. Using the Akaike information criterion with correction for samples of finite size (AICc), we carried out model selection from the full starting model. We then chose the most parsimonious model among those selected within two AIC units of the best model obtained. $P$ values were obtained by stepwise model simplification using likelihood-ratio tests and were considered significant when $p<0.05$. The final model was validated by the graphical checking of normality, independence and variance homogeneity of the residuals. All analyses were performed with R Software using the lme4 v1.1-8 [4] and MuMIn v1.15.1 [3] packages.

\section{Results}

A total of 1604 rodents were sampled (mean trap success: $0.30 \pm 0.11$ ): 689 house mice (Mus musculus domesticus), 513 multimammate rats (376 Mastomys erythroleucus and $137 \mathrm{M}$. natalensis), 334 black rats (Rattus rattus), 39 Nile rats (Arvicanthis niloticus), 25 Dalton's mice (Praomys daltoni), three brown rats (Rattus norvegicus) and one fat mouse (Steatomys sp.) (Table 1). Rodent diversity was relatively low within localities (mean Simpson's diversity index: $0.78 \pm 0.21$ ) (Table 1).

A total of 1205 rodents (Mastomys spp., R. rattus, M. m. domesticus, A. niloticus and P. daltoni) were screened for Toxoplasma antibodies. Among them, we found 44 seropositive rodents (Table 1). MAT titres were: 1:16 in nine, 1:32 in 28, and above 1:320 in seven. The 44 seropositive rodents belonged to four different species: the native M. erythroleucus ( $n=13 ; 4 \%$ of the screened individuals) and M. natalensis $(n=2 ; 2 \%)$, and the invasive M. m. domesticus $(n=25$;
$5 \%$ ), and $R$. rattus $(n=4 ; 2 \%)$. No seropositive individuals were found among $A$. niloticus and $P$. daltoni, represented by very low sample sizes ( $n=23$ and $n=18$, respectively). Within localities, Toxoplasma seroprevalence (mean: $0.04 \pm 0.06)$ ranged from zero (20 localities) to $24 \%$ (code THC) (Fig. 1; Table 1).

Statistical analysis was restricted to data for the four species with sufficient sample sizes (i.e., M. m. domesticus, R. rattus and Mastomys species). Rodent seropositivity was significantly related to latitude (Likelihood Ratio Test $\mathrm{LRT}_{1,1164}=7.91$ $p=0.0049$ ), with higher seroprevalence in northern localities (Fig. 1), but not with longitude (LRT 1,1164 $=0.57, p=0.4520)$, Simpson diversity $\left(\mathrm{LRT}_{1,1164}=0.01\right.$, $p=0.9346)$, trap success $\left(\mathrm{LRT}_{1,1164}=0.22, p=0.6423\right)$, rodent species $\left(\mathrm{LRT}_{3,1164}=0.96, p=0.8103\right)$, sex $\left(\mathrm{LRT}_{1,1164}\right.$ $=0.64, p=0.4254)$ or body mass $\left(\mathrm{LRT}_{1,1164}=0.64\right.$, $p=0.4254)$.

\section{Discussion}

In Senegal, commensal rodent communities are dominated by native Mastomys spp., as well as by the invasive $M . m$. domesticus from the centre to the north of the country, or by $R$. rattus in the southern part [7] (Fig. 1). The distribution of the various species reflects the ongoing eastwards spread of invasive rodents from coastal localities where they were introduced during the colonial era [7, 15, 18].

Mean Toxoplasma seroprevalence was relatively low (4\%) in rodents from Senegal. This value closely matches that found in rodents elsewhere [2, 13, 19, 20, 22]. Low seroprevalence in rodents led to an initial question on the sensitivity of the serological test used to detect $T$. gondii infection. The MAT technique is commonly used in diverse species of animals. It was shown to be a reliable indicator of infection in mice of several laboratory strains $[11,26]$. Seronegative values were nevertheless reported in Mus musculus offspring infected by vertical transmission from chronically infected dams, although the infection was confirmed by PCR [5, 27]. Diverse virulence of a given $T$. gondii strain has been observed in laboratory and wild mouse strains, indicating different innate immunological reactions linked to polymorphic variations in the IRG system $[16,21]$. Also, differences in antibody response against $T$. gondii infection among wild rodent species cannot be excluded. All these elements point out the benefit of combining different techniques of Toxoplasma detection in future studies, in order to evaluate their respective value for the screening of rodent communities in the wild.

Low Toxoplasma seroprevalence is expected under Sahelian climatic conditions (low hygrometry, high soil and air temperatures and ultraviolet irradiation levels), which are poorly suitable for oocysts survival and sporulation [10] and may decrease the probability of environmental contamination [33]. On the basis of this assumption, mean seroprevalence was found to be similarly low in this study and in the only other rodent survey performed in the Sahel (e.g., in Niamey, Niger: $<2 \%$ Toxoplasma seroprevalence in M. m. domesticus, $R$. rattus and $M$. natalensis) [20]. Nevertheless, climatic conditions cannot explain the latitudinal gradient found in Senegal. 
Indeed, in this country the main climatic factor related to latitude is aridity, which would be unfavourable to Toxoplasma transmission but increases from south to north [29] like the number of positive rodents. This unexpected latitudinal pattern suggests the effect of environmental factors other than climate on Toxoplasma seroprevalence in rodents. For instance, the proximity of irrigated surfaces may play a role, as indicated by higher Toxoplasma seroprevalence found in rodents that were sampled within irrigated gardens in Niamey [20]. Seroprevalence values in rodents may also reflect differences in the distribution of other host species such as cats, dogs and livestock, which were found to be largely infected by Toxoplasma in Senegal [8, 12, 28]. For instance, the higher number of positive rodents in the North could relate to the large livestock populations of the Ferlo region, which is the heart of pastoral herding in Senegal [6]. Large populations of domestic cats have been observed in villages in the Senegal River's middle valley (Duplantier, unpublished data), but there are unfortunately no data on the distribution of domestic and wild felids across the country that could help to explain the differences in Toxoplasma seroprevalence found in rodents among the different localities [8].

Variations in $T$. gondii infection were not related to variations in rodent communities among localities (Fig. 1). We would have expected to detect higher seroprevalence values in some species than in others because of differences in body size and home range size (e.g., $R$. rattus larger than $M$. m. domesticus), or in some individuals because of sex or body mass (e.g., $[1,30])$. However, low seroprevalence levels lead to low statistical power to detect the effect of such factors in complex models. Because of their shorter life expectancy and smaller home-range, rodents may be less likely to be infected than larger mammals [1], which raises the question of their role as sentinels for $T$. gondii infection. The specific ecological characteristics of the rodents sampled in this study could also explain the low seroprevalence. Indeed, $R$. rattus (that often build nests in the roofs of houses), or M. m. musculus and Mastomys species (that use crevices or cracks as burrows) are less at risk of being infected by $T$. gondii than fossorial mammals, because they are less in contact with potentially contaminated soil [1].

To our knowledge, this study is the first to focus on Toxoplasma seroprevalence in rodents at the scale of a Sahelian country. To obtain a clearer view of $T$. gondii epidemiology, similar studies in rural areas on other epidemiological agents such as cats, sheep and goats, are necessary. They will enable us to better understand the risk factors related to T. gondii in villages and towns of Senegal, which seem to be variable geographically.

\section{Conflict of interest}

The authors declare that they have no conflict of interest.

Acknowledgements. We thank Jean-Marc Duplantier for his precious help and advice during this work, and all the Senegalese people who allowed us to trap rodents in their homes. Funding was provided by the Institut de Recherche pour le Développement (IRD) and the ANR ENEMI (ANR-11-JSV7-0006).

\section{References}

1. Afonso E, Thulliez P, Pontier D, Gilot-Fromont E. 2007. Toxoplasmosis in prey species and consequences for prevalence in feral cats: not all prey species are equal. Parasitology, 134, 1963-1971.

2. Araujo JB, da Silva AV, Rosa RC, Mattei RJ, da Silva RC, Richini-Pereira VB, Langoni H. 2010. Isolation and multilocus genotyping of Toxoplasma gondii in seronegative rodents in Brazil. Veterinary Parasitology, 174, 328-331.

3. Bartoń K. 2013. MuMIn: multi-model inference. Available from: http://r-forge.r-project.org/projects/mumin/.

4. Bates D, Maechler M, Bolker B, Walker S. 2014. Fitting linear mixed-effects models using lme4. Journal of Statistical Software, 67, 1-47.

5. Beverley JK. 1959. Congenital transmission of toxoplasmosis through successive generations of mice. Nature, 183, 13481349.

6. Cesaro J-D, Magrin C, Ninot O. 2010. Atlas de l'élevage au Sénégal. Cirad, Prodig, ATP Icare: Paris.

7. Dalecky A, Bâ K, Piry S, Lippens C, Diagne CA, Kane M, Sow A, Diallo M, Niang Y, Konecny A, Sarr N, Artige E, Charbonnel N, Granjon L, Duplantier JM, Brouat C. 2015. Range expansion of the invasive house mouse Mus musculus domesticus in Senegal, West Africa: a synthesis of trapping data over three decades, 1983-2014. Mammal Review, 45, 176-190.

8. Davoust B, Mediannikov O, Roqueplo C, Perret C, Demoncheaux J-P, Sambou M, Guillot J, Blaga R. 2014. Enquête de séroprévalence de la toxoplasmose animale au Sénégal. Bulletin de la Société de Pathologie Exotique, 108, 73-77.

9. Desmonts G, Remington JS. 1980. Direct agglutination test for diagnosis of Toxoplasma infection: method for increasing sensitivity and specificity. Journal of Clinical Microbiology, 11, 562-568

10. Dubey JP. 1998. Toxoplasma gondii oocyst survival under defined temperatures. Journal of Parasitology, 84, 862-865.

11. Dubey JP, Thulliez P, Powell EC. 1995. Toxoplasma gondii in Iowa sows: comparison of antibody titers to isolation of T. gondii by bioassays in mice and cats. Journal of Parasitology, $81,48-53$.

12. Garin J-P, Baylet R, Despeignes J, Kien Tuong T, Rioche M, Correa P. 1971. Recherches épidémiologiques sur la toxoplasmose humaine et animale au Sénégal. Médecine d'Afrique Noire, 18, 751-753.

13. Gotteland C, Chaval Y, Villena I, Galan M, Geers R, Aubert D, Poulle ML, Charbonnel N, Gilot-Fromont E. 2013. Species or local environment, what determines the infection of rodents by Toxoplasma gondii? Parasitology, 141, 259-268.

14. Granjon L, Duplantier JM. 2009. Les rongeurs de l'Afrique sahélo-soudanienne. Faune et Flore Tropicales. IRD Editions/ Publications scientifiques du Muséum: Marseille, France.

15. Konečný A, Estoup A, Duplantier JM, Bryja J, Bâ K, Galan M, Tatard C, Cosson J-F. 2013. Invasion genetics of the introduced black rat (Rattus rattus) in Senegal, West Africa. Molecular Ecology, 22, 286-300.

16. Lilue J, Müller UB, Steinfeldt T, Howard JC. 2013. Reciprocal virulence and resistance polymorphism in the relationship between Toxoplasma gondii and the house mouse. eLife, 2, e01298.

17. Lindsay DS, Dubey JP. 2007. Toxoplasmosis in wild and domestic animals, in Toxoplasma gondii: the model apicomplexan, perspective and methods. Weiss L, Kami K, Editors. Academic Press: London. p. 133-152. 
18. Lippens C, Estoup A, Hima K, Loiseau A, Tatard C, Dalecky A, Bâ K, Kane M, Diallo M, Sow A, Niang Y, Piry S, Berthier K, Leblois R, Duplantier JM, Brouat C. 2017. Genetic structure and invasion history of the house mouse (Mus musculus domesticus) in Senegal, West Africa: a legacy of colonial and contemporary times. Heredity, 119, 64-75.

19. Mercier A. 2010. Approche écologique, épidémiologique et génétique de la biodiversité de Toxoplasma gondii en zone tropicale humide: exemples du Gabon et de la Guyane Française. Limoges University.

20. Mercier A, Garba M, Bonnabau H, Kane M, Rossi J-P, Dardé M-L, Dobigny G. 2013. Toxoplasmosis seroprevalence in urban rodents: a survey in Niamey, Niger. Mémorias do Instituto Oswaldo Cruz, 108, 399-407.

21. Müller UB, Howard JC. 2016. The impact of Toxoplasma gondii on the mammalian genome. Current Opinion in Microbiology, 32, 19-25.

22. Muradian V, Ribeiro Ferreira L, Gallucci Lopes E, de Oliveira Esmierini P, de Jesus Pena HF, Martins Soares R, Gennari SM. 2012. A survey of Neospora caninum and Toxoplasma gondii infection in urban rodents from Brazil. Journal of Parasitology, 98, 128-134.

23. Murphy RG, Williams RH, Hughes JM, Hide G, Ford NJ, Oldbury DJ. 2008. The urban house mouse (Mus domesticus) as a reservoir of infection for the human parasite Toxoplasma gondii: an unrecognised public health issue? International Journal of Environmental Health Research, 18, 177-185.

24. Ndiaye D, Sène PD, Ndiaye M, Faye B, Ndiaye JL, Ndir O. 2011. Update on toxoplasmosis prevalence based on serological tests in pregnant women in Dakar, Senegal from 2002 to 2006. Médecine Tropicale, 71, 101-102.
25. Nicolle C, Manceaux L. 1909. Sur un protozoaire nouveau du gondi. Comptes Rendus de l'Académie des Sciences de Paris, $148,369$.

26. Ostfeld RS, Glass GE, Keesing F. 2005. Spatial epidemiology: an emerging (or re-emerging) discipline. Trends in Ecology \& Evolution, 20, 328-336.

27. Owen MR, Trees AJ. 1998. Vertical transmission of Toxoplasma gondii from chronically infected house (Mus musculus) and field (Apodemus sylvaticus) mice determined by polymerase chain reaction. Parasitology, 116, 299-304.

28. Panguit LJ, Gbati OB, KamgaWaladjo AR, Bakou SN. 2013. Point sur la toxoplasmose en Afrique de l'ouest et du centre. Revue Africaine de Santé et de Productions Animales, 11, 2940.

29. Pélissier P. 1983. Atlas du Sénégal. Éditions Jeune Afrique: Paris.

30. Reperant LA, Hegglin D, Tanner I, Fischer C, Deplazes P. 2009. Rodents as shared indicators for zoonotic parasites of carnivores in urban environments. Parasitology, 136, 329-337.

31. Sikes RS, Gannon WI, The Animal Care and Use Committee of the American Society of Mammalogists. 2011. Guidelines of the American Society of Mammalogists for the use of wild mammals in research. Journal of Mammalogy, 92, 235-253.

32. Simpson EH. 1949. Measurement of diversity. Nature, 163, 688.

33. Tenter AM, Heckeroth AR, Weiss LM. 2000. Toxoplasma gondii: from animals to humans. International Journal for Parasitology, 30, 217-220.

Cite this article as: Brouat C, Diagne CA, Ismaï K, Aroussi A, Dalecky A, Bâ K, Kane M, Niang Y, Diallo M, Sow A, Galal L, Piry S, Dardé M \& Mercier A. 2018. Seroprevalence of Toxoplasma gondii in commensal rodents sampled across Senegal, West Africa. Parasite 25, 32 .

\section{PARASTTE}

Reviews, articles and short notes may be submitted. Fields include, but are not limited to: general, medical and veterinary parasitology; morphology, including ultrastructure; parasite systematics, including entomology, acarology, helminthology and protistology, and molecular analyses; molecular biology and biochemistry; immunology of parasitic diseases; host-parasite relationships; ecology and life history of parasites; epidemiology; therapeutics; new diagnostic tools.

All papers in Parasite are published in English. Manuscripts should have a broad interest and must not have been published or submitted elsewhere. No limit is imposed on the length of manuscripts.

Parasite (open-access) continues Parasite (print and online editions, 1994-2012) and Annales de Parasitologie Humaine et Comparée (1923-1993) and is the official journal of the Société Française de Parasitologie. 